\title{
ASSESSING PROFESSIONAL BEHAVIOR PERCEPTIONS BETWEEN COMPUTING, ENGINEERING, AND BUSINESS STUDENTS AND HIRING EMPLOYERS
}

\author{
Cassandra C. Elrod, Ph.D., Missouri University of Science \& Technology, cassa@mst.edu \\ Sarah M. Stanley, Ph.D., Missouri University of Science \& Technology, stanleysm@mst.edu \\ Barry B. Flachsbart, Ph.D., Missouri University of Science \& Technology, barryf@mst.edu \\ Michael G. Hilgers, Ph.D., Missouri University of Science \& Technology, hilgers@mst.edu \\ Elizabeth A. Cudney, Ph.D., Missouri University of Science \& Technology, cudney@mst.edu
}

\begin{abstract}
This paper provides a unique perspective, as it is a collaborative effort between engineering, business, and information science and technology faculty to assess the gap between perceived professionalism in students and potential employers. The goal of the study is to outline similarities and differences to enable the faculty in various areas of study to better prepare students, through curriculum efforts, mentoring, and advising, for future employment. The study identified differences in ways students look for potential employers and how employers recruit potential new hires. Further, the study outlined similarities and differences in how engineering, computing, and business students perceive professionalism behaviors differently than hiring employers.
\end{abstract}

Keywords: Professionalism, Education, Job Recruitment, Social Media

\section{INTRODUCTION}

Faculty frequently hear students' frustration with interviews and job placement for either internships and co-ops or full time employment after graduation. Students may not view their actions in the same light as faculty, who may see those actions as unprofessional and that might make the students unemployable or unsuccessful at the interview process. The desire of educators is to educate students not only on the topics of their expertise, but also in the ways of industry so that they can be successful and productive citizens and hopefully give back to their alma mater in numerous ways (monetarily, speaking, providing internship opportunities to students, etc.). There is a cyclical student-to-industry process that occurs between students seeking employment opportunities, and employers seeking new hires as shown in Figure 1. The goal for both is typically to maximize gains by being hired by a good company or hiring the best recent graduates $[5,7,6,8,10]$.

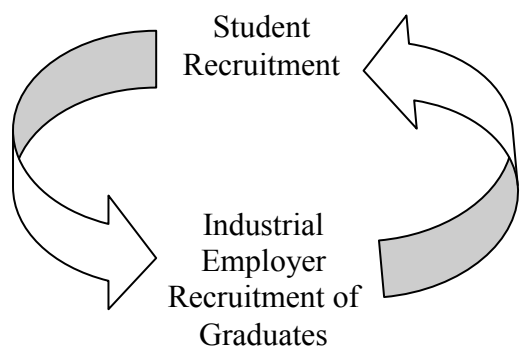

Figure 1. Cyclical Student to Industry Process

The literature has explored the differences in perceptions of students and employers on aspects of professionalism in specific fields of study, such as business schools [13]. This study provides a unique perspective to this long held area of interest by providing a broader perspective of faculty, a survey of students across many areas of study, as well as employers hiring a wide perspective of graduates, not just in one area. The faculty who collaborated on this study are predominately in the areas of technology and engineering, in a very engineering dominated campus where technology is critical. The business program on the campus is even unique, in that it integrates technology to solve business problems.

The literature is well founded in the area of what employers desire and what skills graduating students possess [4]. The National Association of Colleges and Employers notes that high grade point averages are not enough to secure a job 
[22] and that non-technical skills are a requirement for today's jobs. Researchers have also noted a gap that exists between what employers want in new hires and what college graduates possess [22, 14, 23]. According to the National Association of Colleges and Employer's 2010 Job Outlook, the top five desired characteristics are: communication skills, analytical skills, teamwork skills, technical skills (as related to major), and a strong work ethic [22].

It has been noted that academic behavior on college or university campuses may indeed be a predictor, or precursor, to professional behavior in the workplace [29]. The literature is not well founded on the matter of the differences in student and employer perceptions of appropriateness of specific areas of professionalism. The goal of this study is to assess the differences in perceptions of professionalism between students and employers seeking new hires.

\section{BACKGROUND}

There is little debate about one thing: employers look to hire and promote individuals they believe to be professional. What behaviors constitute professionalism and how to instill them as part of the educational process is still very nebulous. This paper seeks to clarify what behaviors are acceptable and unacceptable, and how those perceptions change in the context of a classroom setting versus a professional work environment. By surveying business professionals as well as undergraduate students, the gaps in perception become more apparent. This leads to a broader discussion about how to better prepare students as part of the education process.

Previous research has been performed on related topics of professionalism in academia and the workforce. For instance, one study looked at several current methods of teaching professional behavior in the classroom and asked students, professionals, and faculty the extent to which they agreed with these current methods. In this instance it was clear that while there are some points of consensus, there are many points of disagreement among the groups surveyed [3]. The unique contribution of this research, however, is that it focuses more on the professional behaviors themselves, to understand how expectations change as students' shift from the classroom to the workplace. This is different than the previous research that looked at the methods faculty use to teach professionalism [12], and by looking directly at the student behavior we may be able to better understand how to appropriately begin teaching professional behaviors.

Many other studies have looked at what employers expect from new graduates. These studies exist in many traditional disciplines such as accounting [19, 36], library science and information systems (IS) [29], healthcare [24], construction [11] and communication [35]. They also exist in more novel contexts such as Amazon's Mechanical Turk [15]. In many cases, they break up the employer expectations into categories such as technical knowledge, communication skills, and desirable attitude traits.

Yet other past research addresses specific student skills to better understand their role in the hiring process. Skills such as information literacy [33] and English proficiency [30] have been studied previously. Moreover, studies about the student-employer expectation gap have been studied globally with samples taken in Europe [1], Russia [16] and India [26]. Only a few papers have taken these steps further to include a discussion about how to change or analyze curriculum to better address the gap [17, 21, 25, 34].

The landscape of professional behavior is changing. Memos and meetings are giving way to e-mails and virtual conferences. With these changes, universities still appear to be struggling with technology. Should they embrace it to improve learning or should it be restricted in the classroom? Some research suggests that learning and engagement improve with the use of technology $[12,18]$, while other studies have found it to be a disruption that hampers the student's grade [27]. What is known is that academic dishonesty is more rampant. In fact, self-reported cheating by college students increased 58\% from 1940 to 1982 [9], which leads to questions about how that will affect the workplace as ethical guidelines slip. As a result, many business schools have implemented mandatory ethics classes. A study discussing this trend illustrated that while many business students recognized a behavior as 'unethical' they believed it was too commonplace to stop and even the students realized that this could be related to behaviors in the workforce [29].

Professionalism topics such as cheating have been well researched. The common key finding is that students will cheat more frequently if they feel external pressure [32]. Pressure for grades, academic stress, and inconsistent application of academic rules have also been linked to cheating [9]. Links have also been made between cheating in school followed by professional work in premedical and medical students [31]. Cheating constitutes behavior around 
exams, papers, projects, collection of data, reports, computer ethics, use of academic resources, and adherence to rules and regulations [9].

Other studies have outlined that academians have defined areas of professionalism to include ethics, professional organizations and civility [28]. Further discussion with faculty, career service centers, and business professionals concluded that aspects such as professional appearance, regular attendance, "not having your hand held for everything," "able to be flexible," and "able to take increasing level of responsibility" were things necessary for professionalism [2]. Conclusions based on employer surveys have indicated that managers see professional behaviors such as honesty, ethics, appearance, time management, joining professional organizations, and appropriate meeting behavior as important [13]. Others have focused on academia being able to produce students who do the right thing versus just knowing what is right. It is also thought that these types of things are hard to be taught in the academic environment [37].

\section{METHODOLOGY}

Areas of academic professionalism, as expected from students by the collaborative faculty from engineering, business, and information science and technology, were identified. A questionnaire was developed outlining issues that faculty and employers often find inappropriate in students and new hires. The questionnaire was developed using Qualtrics, and distributed online to gather responses from both current students, as well as industry professionals who are involved in the hiring process at their organization. The questionnaire was developed in light of this study being an exploratory deveavor, and a wide variety of broad questions were used with the expectations that the results would unveil more specific issues to address in further studies. A variety of outlets were used to distribute the survey to ensure a representative sample from each population being surveyed. Thirty-two responses were obtained from current students, and 60 responses were obtained from industry professionals involved in the hiring process. Demographic information was obtained including information such as gender, age, college major, household income range, race, and employment status. Questions such as "Please rate how acceptable you think expecting immediate assistance from your supervisor/professor (drop everything and help me) is," "Please rate how acceptable you think cheating/lying on tasks assigned is," and "Please rate how acceptable you think using unauthorized materials for tasks/assignment/projects/exams is." The scale used was $1=$ unacceptable, $2=$ questionable, and $3=$ acceptable. The weighted averages for each question per group were calculated for an overall representation of their perceptions.

After the results were collected, the responses were compared to assess the gap between what students perceive as "more acceptable" in the academic setting versus the employment setting. The gap between student and employer perceptions of acceptableness of various professionalism topics was also determined.

\section{FINDINGS AND DISCUSSION}

The sample ( $\mathrm{n}=92)$ was comprised of 32 students and 60 hiring professionals. The sample size was $38 \%$ female and $62 \%$ male. Because the sample was collected via online distribution, the sample was also very diverse in terms of location of respondents and was comprised of respondents from every continent except South America.

Of the students that responded, $94 \%$ of them were between the ages of 18 and 34, with the majority ranging between $18-24(60 \%)$. The student respondents also varied in terms of education, but $87 \%$ had at least some college education.

The student respondents' current enrollment consisted mainly of bachelor's degree level of study (63\%), however there were all levels represented from associate's degree to doctoral level. The student respondent ethnic backgrounds were diverse, including White/Caucasian (50\%), Black/African American (3\%), Asian (34\%), and Native American (13\%).

The student population was also studying a variety of majors. The student respondents were studying computer science $(23 \%)$, business $(17 \%)$, engineering (13\%), as well as accounting, economics, humanities, physical science, and social science.

An area of interest in this study was how students connect with potential employers. The student respondents reported that $61 \%$ of them do use social media outlets to connect with employers, specifically, Facebook (21\%), Google+ (11\%), LinkedIn (27\%), and Twitter (5\%). Another 17\% indicated using job boards online and $19 \%$ indicated the use of employee referrals as a means to connect with potential employers (see Figure 2). It is also worth noting that $69 \%$ of the student respondents indicated they were currently looking for full-time employment, an internship, or a co-op. 
How Students Connect with Potential Employers By Percentage

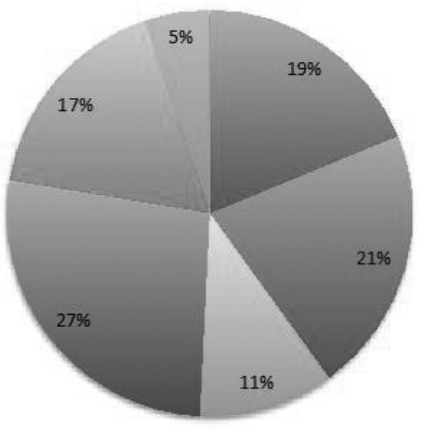

= Employee referrals

Figure 2. How Students Connect with Potential Employers

Of the employer respondents, $69 \%$ were male and $31 \%$ were female. The majority of the age group reporting was $25-$ $34(59 \%)$, with ages 35-44 (22\%) being the next largest age demographic. Interestingly, all of the hiring employer respondents reported their highest level of education being at least some level of college (14\%), $2 \%$ holding an associate's degree, $42 \%$ holding a bachelor's degree, and $42 \%$ holding a graduate or professional degree. The ethnic background of the employer respondent group was also diverse, including Asian (53\%), White/Caucasian (32\%), and small groups from Spanish/Hispanic/Latino, Black/African American, Pacific Islander, Native American, and "other" groups.

Interestingly enough, even though the majority of the employer respondents were one to two age groups older than the student respondents, $50 \%$ of them reported using social media to connect to potential candidates for hire. Specifically, the employer respondents indicated using job boards (37\%), Facebook (22\%), employee referrals (22\%), LinkedIn $(17 \%)$, Google $+(2 \%)$, and Twitter $(0 \%)$ for recruiting potential candidates to hire (see Figure 3 ).

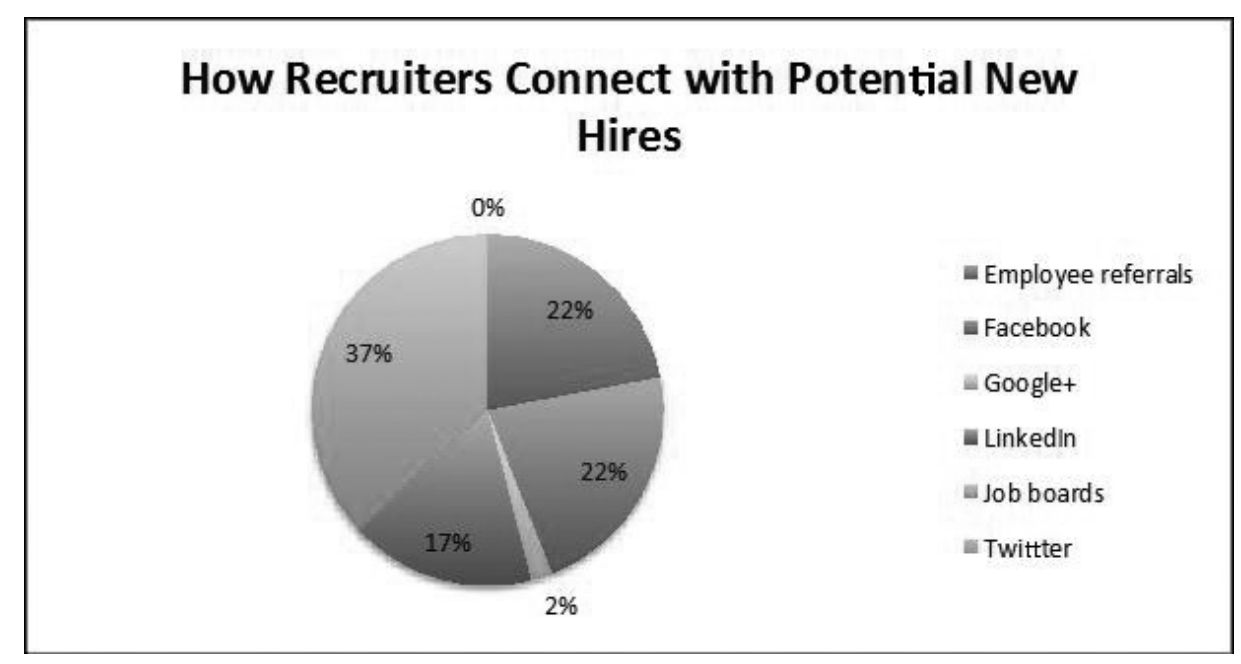

Figure 3. How Recruiters Connect with Potential Candidates

Table 1 outlines the questions asked, regarding professionalism behaviors at work, to student respondents and their answers ranging from "unacceptable" to "acceptable," as well as the weighted averages for these responses. 


\section{Issues in Information Systems \\ Volume 16, Issue I, pp. 69-79, 2015}

Table 1. Student Perceptions of Professionalism Appropriateness at Work

\begin{tabular}{|c|c|c|c|c|c|c|}
\hline & Professionalism Question & Unacceptable (1) & Questionable (2) & Acceptable (3) & Total Responses & Weighted Avg \\
\hline 1 & Scheduling vacation during known meetings/classes & 20 & 8 & 5 & \begin{tabular}{|r|r}
33 \\
\end{tabular} & 1.55 \\
\hline 2 & $\begin{array}{l}\text { Hanging out in a supervisor's/professor's office to kill } \\
\text { time }\end{array}$ & 12 & 11 & 6 & 29 & 1.79 \\
\hline 3 & $\begin{array}{l}\text { Thanking someone for feedback and/or constructive } \\
\text { criticism }\end{array}$ & 2 & 5 & 26 & 33 & 2.73 \\
\hline 4 & Not reading assigned meeting/class materials & 21 & 10 & 0 & 31 & 1.32 \\
\hline 5 & $\begin{array}{l}\text { Not addressing someone by their appropriate title (i.e. } \\
\text { Mr. Ms., Dr., etc) }\end{array}$ & 13 & 17 & 5 & 35 & 1.77 \\
\hline 6 & Attending meetings/class unprepared & 21 & 11 & 3 & 35 & 1.49 \\
\hline 7 & Interrupting a conversation between others & 16 & 16 & 3 & 35 & 1.63 \\
\hline 8 & Entering an office without knocking & 20 & 11 & 2 & 33 & 1.45 \\
\hline 9 & $\begin{array}{l}\text { Walking in to an office without being } \\
\text { acknowledged/invited }\end{array}$ & 14 & 14 & 1 & 29 & 1.55 \\
\hline 10 & $\begin{array}{l}\text { Expecting immediate assistance from } \\
\text { supervisor/professor (drop everything and help me) }\end{array}$ & 20 & 7 & 3 & 30 & 1.43 \\
\hline 11 & Doing the minimum and expecting maximum reward & 19 & 10 & 3 & 32 & 1.50 \\
\hline 12 & $\begin{array}{l}\text { Inquiring about minimum effort to achieve pay } \\
\text { raise/bonus points }\end{array}$ & 15 & 15 & 4 & 34 & 1.68 \\
\hline 13 & Dressing more casual than the average peer & 13 & 15 & 7 & 35 & 1.83 \\
\hline 14 & Dressing provocatively at work/school & 21 & 7 & 2 & 30 & 1.37 \\
\hline 15 & Waiting until the last minute to do assigned tasks & 12 & 15 & 4 & 31 & 1.74 \\
\hline 16 & Skipping meetings/classes & 23 & 4 & 2 & 29 & 1.28 \\
\hline 17 & Being 5 minutes late to meetings/classes & 12 & 12 & 8 & 32 & 1.88 \\
\hline 18 & Being 10 minutes late to meetings/classes & 21 & 8 & 3 & 32 & 1.44 \\
\hline 19 & Lying to your boss/professor & 18 & 10 & 3 & 31 & 1.52 \\
\hline 20 & $\begin{array}{l}\text { Telling your boss/professor "I finished this } \\
\text { project/assignment but it was a waste of time" }\end{array}$ & 19 & 12 & 2 & 33 & 1.48 \\
\hline 21 & $\begin{array}{l}\text { Gestures such as rolling your eyes during } \\
\text { meetings/class }\end{array}$ & 18 & 8 & 3 & 29 & 1.48 \\
\hline 22 & Cheating/lying on tasks assigned & 27 & 5 & 0 & 32 & 1.16 \\
\hline 23 & $\begin{array}{l}\text { Using unauthorized materials for } \\
\text { tasks/assignments/projects/exams }\end{array}$ & 20 & 10 & 6 & 36 & 1.61 \\
\hline 24 & Missing deadlines for forms/projects/assignments/etc & 21 & 8 & 2 & 31 & 1.39 \\
\hline 25 & $\begin{array}{l}\text { Turning in partially done } \\
\text { tasks/assignments/projects/exams just to avoid major } \\
\text { penalty }\end{array}$ & 17 & 13 & 3 & 33 & 1.58 \\
\hline 26 & Emailing or texting during meetings/class & 12 & 14 & 5 & 31 & 1.77 \\
\hline 27 & Leaving meetings/class early without prior notification & 19 & 11 & 4 & 34 & 1.56 \\
\hline 28 & $\begin{array}{l}\text { Reading class or meeting material during the } \\
\text { class/meeting }\end{array}$ & 6 & 13 & 10 & 29 & 2.14 \\
\hline
\end{tabular}

The same questions were asked of students and their perception of this behavior at school. Table 2 outlines the questions asked, regarding professionalism behaviors at school, to student respondents and their answers ranging from "unacceptable" to "acceptable," as well as the weighted averages for these responses. 
Table 2. Student Perceptions of Professionalism Appropriateness at School

\begin{tabular}{|c|c|c|c|c|c|c|}
\hline & Professionalism Question & Unacceptable (1) & Questionable (2) & Acceptable (3) & Total Responses & Weighted Avg \\
\hline 1 & Scheduling vacation during known meetings/classes & 17 & 8 & 9 & 34 & 1.76 \\
\hline 2 & $\begin{array}{l}\text { Hanging out in a supervisor's/professor's office to kill } \\
\text { time }\end{array}$ & 17 & 10 & 8 & 35 & 1.74 \\
\hline 3 & $\begin{array}{l}\text { Thanking someone for feedback and/or constructive } \\
\text { criticism }\end{array}$ & 6 & 1 & 26 & 33 & 2.61 \\
\hline 4 & Not reading assigned meeting/class materials & 17 & 12 & 3 & 32 & 1.56 \\
\hline 5 & $\begin{array}{l}\text { Not addressing someone by their appropriate title (i.e. } \\
\text { Mr. Ms., Dr., etc) }\end{array}$ & 16 & 12 & 6 & 34 & 1.71 \\
\hline 6 & Attending meetings/class unprepared & 18 & 13 & 3 & 34 & 1.56 \\
\hline 7 & Interrupting a conversation between others & 17 & 15 & 3 & 35 & 1.60 \\
\hline 8 & Entering an office without knocking & 19 & 13 & 3 & 35 & 1.54 \\
\hline 9 & $\begin{array}{l}\text { Walking in to an office without being } \\
\text { acknowledged/invited }\end{array}$ & 14 & 14 & 3 & 31 & 1.65 \\
\hline 10 & $\begin{array}{l}\text { Expecting immediate assistance from } \\
\text { supervisor/professor (drop everything and help me) }\end{array}$ & 19 & 12 & 5 & 36 & 1.61 \\
\hline 11 & Doing the minimum and expecting maximum reward & 20 & 8 & 5 & 33 & 1.55 \\
\hline 12 & $\begin{array}{l}\text { Inquiring about minimum effort to achieve pay } \\
\text { raise/bonus points }\end{array}$ & 13 & 14 & 7 & 34 & 1.82 \\
\hline 13 & Dressing more casual than the average peer & 8 & 8 & 13 & 29 & 2.17 \\
\hline 14 & Dressing provocatively at work/school & 19 & 13 & 4 & 36 & 1.58 \\
\hline 15 & Waiting until the last minute to do assigned tasks & 10 & 16 & 5 & 31 & 1.84 \\
\hline 16 & Skipping meetings/classes & 16 & 17 & 4 & 37 & 1.68 \\
\hline 17 & Being 5 minutes late to meetings/classes & 9 & 18 & 7 & 34 & 1.94 \\
\hline 18 & Being 10 minutes late to meetings/classes & 16 & 11 & 5 & 32 & 1.66 \\
\hline 19 & Lying to your boss/professor & 23 & 10 & 3 & 36 & 1.44 \\
\hline 20 & $\begin{array}{l}\text { Telling your boss/professor "I finished this } \\
\text { project/assignment but it was a waste of time" }\end{array}$ & 21 & 10 & 2 & 33 & 1.42 \\
\hline 21 & $\begin{array}{l}\text { Gestures such as rolling your eyes during } \\
\text { meetings/class }\end{array}$ & 20 & 12 & 4 & 36 & 1.56 \\
\hline 22 & Cheating/lying on tasks assigned & 24 & 6 & 3 & 33 & 1.36 \\
\hline 23 & $\begin{array}{l}\text { Using unauthorized materials for } \\
\text { tasks/assignments/projects/exams }\end{array}$ & 22 & 6 & 3 & 31 & 1.39 \\
\hline 24 & Missing deadlines for forms/projects/assignments/etc & 18 & 11 & 2 & 31 & 1.48 \\
\hline 25 & $\begin{array}{l}\text { Turning in partially done } \\
\text { tasks/assignments/projects/exams just to avoid major } \\
\text { penalty }\end{array}$ & 10 & 15 & 7 & 32 & 1.91 \\
\hline 26 & Emailing or texting during meetings/class & 12 & 17 & 7 & 36 & 1.86 \\
\hline 27 & Leaving meetings/class early without prior notification & 17 & 13 & 1 & 31 & 1.48 \\
\hline 28 & $\begin{array}{l}\text { Reading class or meeting material during the } \\
\text { class/meeting }\end{array}$ & 8 & 12 & 15 & 35 & 2.20 \\
\hline
\end{tabular}

Figure 4 shows the trends in responses from students and outlines the gaps in student respondents' perceptions of how acceptable specific behaviors are either at work or at school. The general trend indicates that students perceive most behaviors as more appropriate at school, versus work. "Using unauthorized materials for tasks/assignments/projects/exams" was perceived as more appropriate, by student respondents, in the work setting versus the school setting. The irony, as indicated in the above discussion, is that previous research has indicated that students cannot merely "flip a switch" and suddenly become more professional in their actions once they leave school and become a part of the workforce. 


\section{Issues in Information Systems}

Volume 16, Issue I, pp. 69-79, 2015

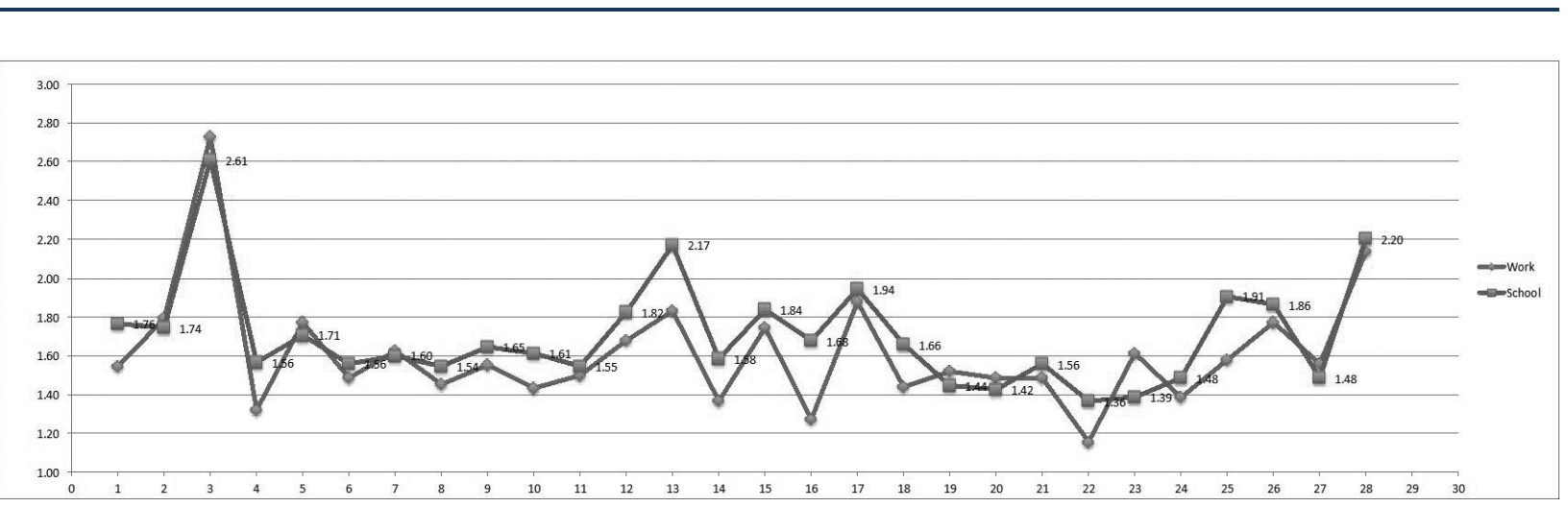

Figure 4. Student Perceptions of Professionalism Appropriateness - Work vs. School

Table 3 outlines the questions asked, regarding professionalism behaviors at work, to employer respondents and their answers ranging from "unacceptable" to "acceptable," as well as the weighted averages for these responses.

Table 3. Employer Perceptions of Professionalism Appropriateness at Work

\begin{tabular}{|c|c|c|c|c|c|c|}
\hline & Professionalism Question & Unacceptable (1) & Questionable (2) & Acceptable (3) & Total Responses & Weighted Avg \\
\hline 1 & Scheduling vacation during known meetings/classes & 39 & 22 & 5 & 66 & 1.48 \\
\hline 2 & $\begin{array}{l}\text { Hanging out in a supervisor's/professor's office to kill } \\
\text { time }\end{array}$ & 34 & 29 & 12 & 75 & 1.71 \\
\hline 3 & $\begin{array}{l}\text { Thanking someone for feedback and/or constructive } \\
\text { criticism }\end{array}$ & 9 & 14 & 39 & 62 & 2.48 \\
\hline 4 & Not reading assigned meeting/class materials & 36 & 25 & 11 & 72 & 1.65 \\
\hline 5 & $\begin{array}{l}\text { Not addressing someone by their appropriate title (i.e. - } \\
\text { Mr. Ms., Dr., etc) }\end{array}$ & 22 & 24 & 12 & 58 & 1.83 \\
\hline 6 & Attending meetings/class unprepared & 37 & 22 & 8 & 67 & 1.57 \\
\hline 7 & Interrupting a conversation between others & 26 & 27 & 9 & 62 & 1.73 \\
\hline 8 & Entering an office without knocking & 39 & 22 & 7 & 68 & 1.53 \\
\hline 9 & $\begin{array}{l}\text { Walking in to an office without being } \\
\text { acknowledged/invited }\end{array}$ & 27 & 30 & 8 & 65 & 1.71 \\
\hline 10 & $\begin{array}{l}\text { Expecting immediate assistance from } \\
\text { supervisor/professor (drop everything and help me) }\end{array}$ & 31 & 22 & 11 & 64 & 1.69 \\
\hline 11 & Doing the minimum and expecting maximum reward & 42 & 17 & 11 & 70 & 1.56 \\
\hline 12 & $\begin{array}{l}\text { Inquiring about minimum effort to achieve pay } \\
\text { raise/bonus points }\end{array}$ & 31 & 20 & 11 & 62 & 1.68 \\
\hline 13 & Dressing more casual than the average peer & 25 & 34 & 12 & 71 & 1.82 \\
\hline 14 & Dressing provocatively at work/school & 36 & 18 & 12 & 66 & 1.64 \\
\hline 15 & Waiting until the last minute to do assigned tasks & 22 & 23 & 15 & 60 & 1.88 \\
\hline 16 & Skipping meetings/classes & 36 & 22 & 10 & 68 & 1.62 \\
\hline 17 & Being 5 minutes late to meetings/classes & 24 & 25 & 11 & 60 & 1.78 \\
\hline 18 & Being 10 minutes late to meetings/classes & 34 & 25 & 10 & 69 & 1.65 \\
\hline 19 & Lying to your boss/professor & 42 & 20 & 10 & 72 & 1.56 \\
\hline 20 & $\begin{array}{l}\text { Telling your boss/professor "I finished this } \\
\text { project/assignment but it was a waste of time" }\end{array}$ & 38 & 20 & 8 & 66 & 1.55 \\
\hline 21 & Gestures such as rolling your eyes during meetings/class & 29 & 28 & 13 & 70 & 1.77 \\
\hline 22 & Cheating/lying on tasks assigned & 42 & 17 & 5 & 64 & 1.42 \\
\hline 23 & $\begin{array}{l}\text { Using unauthorized materials for } \\
\text { tasks/assignments/projects/exams }\end{array}$ & 39 & 19 & 8 & 66 & 1.53 \\
\hline 24 & Missing deadlines for forms/projects/assignments/etc & 37 & 20 & 7 & 64 & 1.53 \\
\hline 25 & $\begin{array}{l}\text { Turning in partially done } \\
\text { tasks/assignments/projects/exams just to avoid major } \\
\text { penalty }\end{array}$ & 30 & 21 & 10 & 61 & 1.67 \\
\hline 26 & Emailing or texting during meetings/class & 25 & 30 & 12 & 67 & 1.81 \\
\hline 27 & Leaving meetings/class early without prior notification & 32 & 25 & 8 & 65 & 1.63 \\
\hline 28 & $\begin{array}{l}\text { Reading class or meeting material during the } \\
\text { class/meeting }\end{array}$ & 18 & 33 & 14 & 65 & 1.94 \\
\hline
\end{tabular}

Table 4 outlines the questions asked, regarding professionalism behaviors at school, to employer respondents and their answers ranging from "unacceptable" to "acceptable," as well as the weighted averages for these responses. 


\section{Issues in Information Systems}

Volume 16, Issue I, pp. 69-79, 2015

Table 4. Employer Perceptions of Professionalism Appropriateness at School

\begin{tabular}{|c|c|c|c|c|c|c|}
\hline & Professionalism Question & Unacceptable (1) & Questionable (2) & Acceptable (3) & Total Responses & Weighted Avg \\
\hline 1 & Scheduling vacation during known meetings/classes & 30 & 16 & 16 & \begin{tabular}{|c|}
62 \\
\end{tabular} & 1.77 \\
\hline 2 & $\begin{array}{l}\text { Hanging out in a supervisor's/professor's office to kill } \\
\text { time }\end{array}$ & 22 & 21 & 11 & 54 & 1.80 \\
\hline 3 & $\begin{array}{l}\text { Thanking someone for feedback and/or constructive } \\
\text { criticism }\end{array}$ & 10 & 14 & 42 & 66 & 2.48 \\
\hline 4 & Not reading assigned meeting/class materials & 30 & 18 & 6 & 54 & 1.56 \\
\hline 5 & $\begin{array}{l}\text { Not addressing someone by their appropriate title (i.e. - } \\
\text { Mr. Ms., Dr., etc) }\end{array}$ & 24 & 30 & 12 & 66 & 1.82 \\
\hline 6 & Attending meetings/class unprepared & 26 & 19 & 9 & 54 & 1.69 \\
\hline 7 & Interrupting a conversation between others & 29 & 22 & 10 & 61 & 1.69 \\
\hline 8 & Entering an office without knocking & 30 & 22 & 3 & 55 & 1.51 \\
\hline 9 & $\begin{array}{l}\text { Walking in to an office without being } \\
\text { acknowledged/invited }\end{array}$ & 32 & 28 & 8 & 68 & 1.65 \\
\hline 10 & $\begin{array}{l}\text { Expecting immediate assistance from } \\
\text { supervisor/professor (drop everything and help me) }\end{array}$ & 29 & 16 & 14 & 59 & 1.75 \\
\hline 11 & Doing the minimum and expecting maximum reward & 33 & 15 & 9 & 57 & 1.58 \\
\hline 12 & $\begin{array}{l}\text { Inquiring about minimum effort to achieve pay } \\
\text { raise/bonus points }\end{array}$ & 25 & 26 & 9 & 60 & 1.73 \\
\hline 13 & Dressing more casual than the average peer & 19 & 20 & 15 & 54 & 1.93 \\
\hline 14 & Dressing provocatively at work/school & 26 & 21 & 11 & 58 & 1.74 \\
\hline 15 & Waiting until the last minute to do assigned tasks & 25 & 25 & 8 & 58 & 1.71 \\
\hline 16 & Skipping meetings/classes & 31 & 19 & 7 & 57 & 1.58 \\
\hline 17 & Being 5 minutes late to meetings/classes & 22 & 32 & 9 & 63 & 1.79 \\
\hline 18 & Being 10 minutes late to meetings/classes & 32 & 19 & 5 & 56 & 1.52 \\
\hline 19 & Lying to your boss/professor & 37 & 9 & 5 & 51 & 1.37 \\
\hline 20 & $\begin{array}{l}\text { Telling your boss/professor "I finished this } \\
\text { project/assignment but it was a waste of time" }\end{array}$ & 31 & 18 & 8 & 57 & 1.60 \\
\hline 21 & Gestures such as rolling your eyes during meetings/class & 30 & 24 & 3 & 57 & 1.53 \\
\hline 22 & Cheating/lying on tasks assigned & 40 & 18 & 6 & 64 & 1.47 \\
\hline 23 & $\begin{array}{l}\text { Using unauthorized materials for } \\
\text { tasks/assignments/projects/exams }\end{array}$ & 38 & 18 & 8 & 64 & 1.53 \\
\hline 24 & Missing deadlines for forms/projects/assignments/etc & 34 & 24 & 8 & 66 & 1.61 \\
\hline 25 & $\begin{array}{l}\text { Turning in partially done } \\
\text { tasks/assignments/projects/exams just to avoid major } \\
\text { penalty }\end{array}$ & 30 & 26 & 13 & 69 & 1.75 \\
\hline 26 & Emailing or texting during meetings/class & 26 & 27 & 11 & 64 & 1.77 \\
\hline 27 & Leaving meetings/class early without prior notification & 30 & 25 & 9 & 64 & 1.67 \\
\hline 28 & $\begin{array}{l}\text { Reading class or meeting material during the } \\
\text { class/meeting }\end{array}$ & 18 & 29 & 17 & 64 & 1.98 \\
\hline
\end{tabular}

Figure 5 shows the trends in responses from employers and outlines the gaps in employer respondents' perceptions of how acceptable specific behaviors are either at work or at school. The general trend indicates that employers perceive most behaviors as relatively the same in acceptability at both work and school, with a few more behaviors more acceptable at work than at school. For example, "Lying to your boss/professor" and "Gestures such as rolling your eyes during meetings/class," were deemed as more acceptable at work than at school by employer respondents. This is an interesting finding, perhaps because employers see the work setting as an "among peers" type of setting versus the faculty-student relationship most are familiar with. 


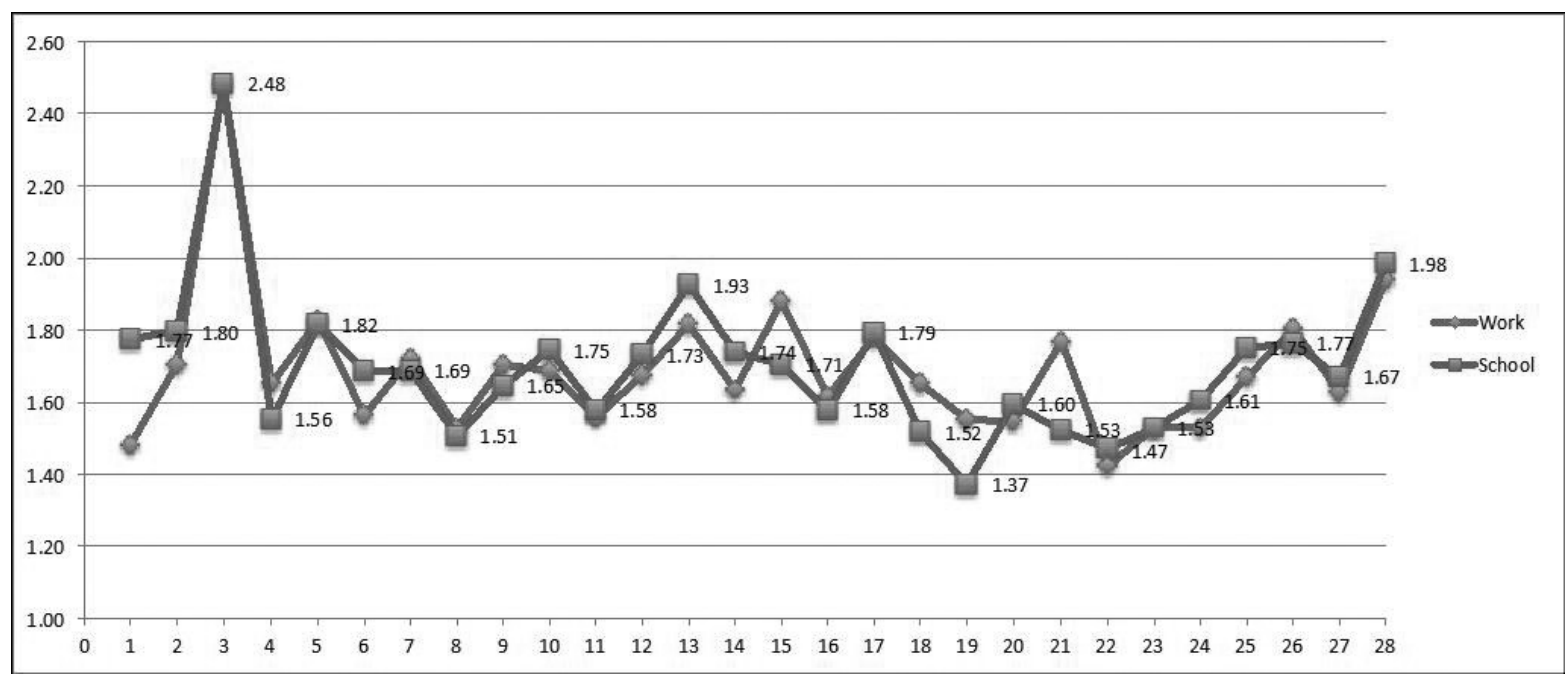

Figure 5. Employer Perceptions of Professionalism Appropriateness - Work vs. School

Finally, Figure 6 outlines the overall differences and trends in perceptions of the student respondent and the employer respondent in both the work and school environments. In general, the student respondent perceives behaviors as overall less acceptable in the work environment and more acceptable in the school environment than the employers' perceptions. The employers' perceptions tend to switch back and forth between certain behaviors on what is more acceptable at school, and what is more acceptable at work.

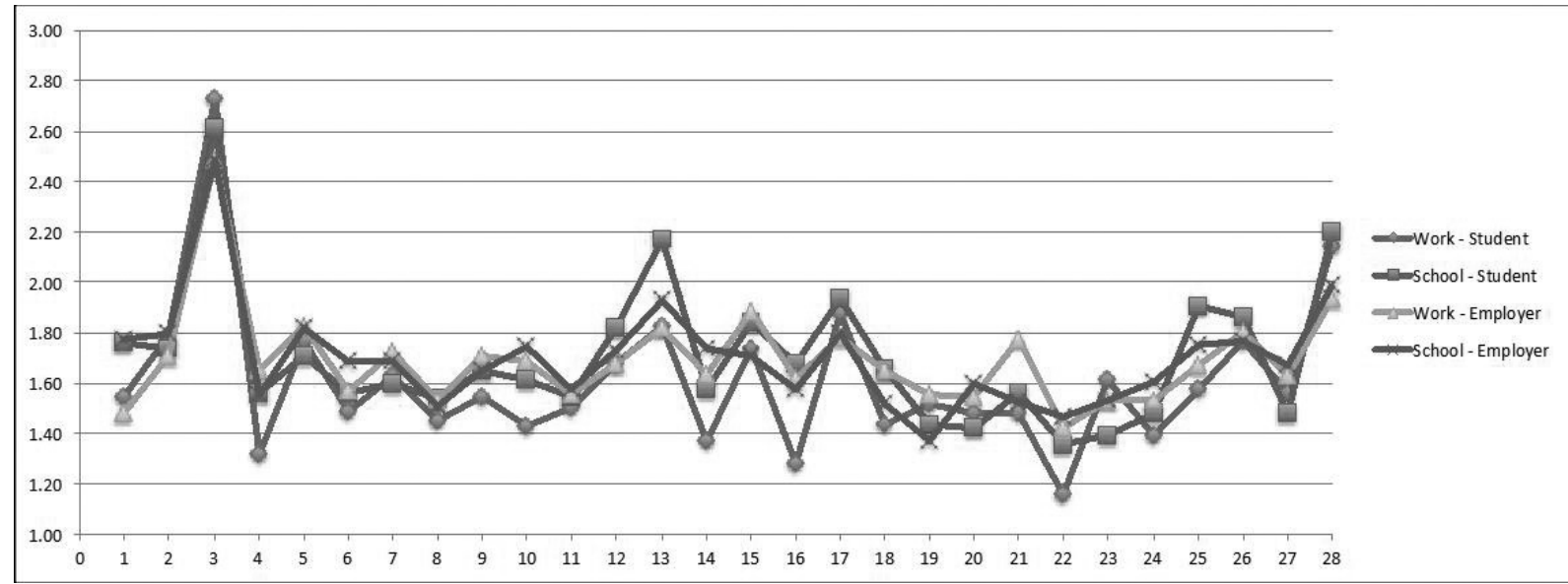

Figure 6. Employer and Student Perceptions of Professionalism Appropriateness - Work vs. School

\section{LIMITATIONS}

As with most studies, there are inherent limitations and recommendations for future studies that are derived from these limitations. Perhaps a possible first limitation is in the nature of the survey instrument itself. As with other studies conducted in the past [2], the professional behaviors used in this study were derived by the collaborative faculty from engineering, business, and information science and technology based on student issues in class and issues mentioned to the faculty from employers recruiting students from these departments. Further identification of other professionalism behaviors could be conducted in the future. As with most online survey distributions, another possible limitation to this study revolves around not being able to confirm, in person, the student or hiring employer status. Finally, further data could be collected in a larger sample size and the results reported by department and used to compare the strengths and weaknesses of each type of major of study. 


\section{CONCLUSIONS}

Overall, this study revealed differences in methods of students and hiring employers in how they recruit students. Employers rely heavily on job boards while students try to connect with potential employers mainly using LinkedIn. This discrepancy may allow for many missed opportunities to connect for both students looking for employment and employers wishing to recruit the best hires.

The student respondent groups tended to rate professional behaviors in question "more appropriate" at school than in the work environment. Perhaps this is due to the common notion that students "pay to go to school, so they can do as they wish" versus an employer paying their salaries. However, conversely, employers viewed several professionalism behaviors as more appropriate at work than at school. Perhaps this is due to them seeing employees as a peer-to-peer relationship, rather than the faculty-student relationship that they are accustomed to. The general notion in the literature is, however, that students cannot merely flip a switch from school to work and become "professional." Conduct and behavior in the school setting is a predictor of performance in the work setting.

Overall, this study has shown that there are discrepancies between engineering, business, and computer sciences students and hiring employer perceptions regarding what is acceptable and unacceptable in the school versus work setting. The collaborative faculty participating in this study hope to be able to convey some of these differences to students through curriculum, advising, and mentoring to enable them to maximize their skill set and improve their employability. The holistic approach to academics stems much farther than just instruction in the classroom. Curriculum development, content, and delivery is relevant to the professionalism issues addressed herein, as to be the most efficient, academia should take a holistic approach to education and include instruction of course related materials, along with professionalism expectation both in and out of the classroom.

\section{REFERENCES}

1. Andrews, J., \& Higson, H. (2008). Graduate employability, 'soft skills' versus 'hard' nusiness knowledge: A European study. Higher Education of Europe, 33(4), p. 11.

2. Calongne, L., \& Matthews, T. (2002). Developing and hiring for critical skills: A faculty, employer, and career services initiative. Journal of Management Research, 3, p. 5.

3. Davis, J. R., \& Welton, R.E. (1991). Professional ethics: Business students' perceptions. Journal of Business Ethics, 10, p. 12.

4. Dupre, C., \& Williams, K. (2011). Undergraduates' perceptions of employer expectations. Journal of Career and Technical Education, 26(1), p. 11.

5. Elrod, C. C. (2007). The development and application of a systematic approach to evaluating an academic department's brand meaning, in Engineering Management \& Systems Engineering. University of Missouri, Rolla: Rolla, MO.

6. Elrod, C. C., Flachsbart, B. B., \& Kehr, W. R. (2009). Improving student employability By Embedding Marketing Concepts in Information Science and Technology Courses. Issues in Information Systems, 10(1), p. 7.

7. Elrod, C. C., Daughton, W. J. Murray, S. L., \& Flachsbart, B. B. (2010). Evaluating the engineering management brand meaning. Engineering Management Journal, 22(2), p. 10.

8. Elrod, C. C., Grantham Lough, K. A., \& K. D. Adams, (2011). Assessing the brand meaning of an interdisciplinary engineering program through a branding method. Journal of Design Research, 9(3), p. 27.

9. Fass, R. A., (1990). Cheating and plagiarism, in ethics and higher education. American Council on Education and MacMillan Publishing, p. 170-184.

10. Flachsbart, B. B. \& Elrod, C. C.. (2011). Graduate to industry supply chain: Post-graduation perception of the value of embedding marketing concepts in Information Science and Technology courses. Issues in Information Systems, 12(2), p. 8.

11. Gao, L., \& Eldin, N. (2014). Employers' expectations: A probabilistic text mining model. Procedia Engineering, 85, p. 7.

12. Gikas, J., \& Grant, M. M. (2013). Mobile computing devices in higher education: Student perspectives on learning with cellphones, smartphones \& social media. Internet and Higher Education, 19, p. 8.

13. Hall, A., \& Berardino, L. (2006). Teaching professional behaviors: Differences in the perceptions of faculty, students and employers. Journal of Business Ethics, 63, p. 8.

14. Hannerman, L., \& Gardner, P. (2010). Under the economic turmoil a skills gap simmers, in collegiate employment research institute M.S. University, Editor. 


\section{Issues in Information Systems}

Volume 16, Issue I, pp. 69-79, 2015

15. Horton, J. J. (2010). Employer expectations, peer effects and productivity: Evidence from a series of field experiments. cs.HC: ar.Xiv:1008.2437v1.

16. Iashkov, A. B. (2012). Graduates and employer. Russian Education \& Society, 54(1). p. 7.

17. Ictenbas, B. D., \& Eryilmaz, H. (2011). Linking employers' expectations with teaching methods: Quality function deployment approach. Procedia: Social and Behavioral Sciences, 28, p. 5.

18. Junco, R., Heibergert, G., \& Loken, E. (2010). The effect of Twitter on college student engagement and grades. Journal of Computer Assisted Learning, p. 14.

19. Kavanagh, M. H., \& Drennan, L. (2015). What skills and attributes does an accounting graduate need? Evidence from student perceptions and employer expectations. Accounting \& Finance, 48(2), p. 22.

20. Kennan, M. A., Willard, P., \& Wilson, C. S. (2006). What do they want? A study of changing employer expectations of information professionals. Australlian Academic and Research Libraries, 31(1), p. 19.

21. Kesner, R. M. (2008). Business school undergraduate Information Management competencies: A study of employer expectations and associated curricular recommendations. Communications of the Association for Information Systems, 23, p. 21.

22. Koc, E., \& Koncz, A. (2009). Job Outlook 2010, N.A.o.C.a. Employers, Editor. Bethlehem, PA.

23. Koc, E. (2010). Hiring up 5.3 percent for class of 2010. Available: http://careerinsider.blogs.bucknell.edu/2010/04/19/good-news-on-the-job-outlook-hiring-up-5-3-percent-forclass-of-2010

24. Krentz, S. E. (1997). Maximizing financial returns by meeting employer expectations. Healthcare Financial Management, 51(5), p. 3.

25. Lim, N. C. (2015). Towards an integrated academic assessment: Closing employers' expectations? Education \& Training, 57(2), p. 22.

26. Malik, R. (2012). Management education and corporate expectations: Bridging the gap. Drishtikon Management Journal, 3(1), p. 28.

27. McDonald, S. E., (2013). The effects and predictor value of in-class texting behavior on final course grades. College Student Journal, 47(1).

28. Moss, H. K., \& Kinnear, T. (2005). Using competency-based student portfolios for assessment of an undergraduate management program. The International Journal of Business Disciplines, 16(1), p. 8.

29. Ogilby, S. M. (1995). The ethics of academic behavior: Will it affect professional behavior? Journal of Education for Business, 71(2).

30. Robbins, J. F. (1988). Employers' language expectations and nonstandard dialect speakers. English Journal, $77(6)$, p. 3.

31. Sierles, F., Hendrickx, I., \& Circle, S. (1980). Cheating in medical school. Journal of Medical Education, 55, p. 2.

32. Smith, C. P., Ryan, E. R., \& Diggins, D. R. (1972). Moral decision making: Cheating on examinations. Moral Decision Making: Cheating on Examinations, 40, p. 20.

33. Sokoloff, J. (2012). Information literacy in the workplace: Employer expectations. Journal of Business \& Finance Librarianship, 17, p. 17.

34. Trank, C. Q., \& Rynes, S. L. (2003). Who moved our cheese? Reclaiming professionalism in business education. Academy of Management Learning and Education, 2(2), p. 16.

35. Treadwell, D. F., \& Treadwell, J. B. (1999). Employer expectations of newly-hired communication graduates. Journal of the Association for Communication Administration, 128, p. 12.

36. Whiteley, S. (1993). The society responds to employer expectations, CMA Magazine, 67(6), p. 1.

37. Woo, C. Y. (2003). Personally responsible, in BizEd, p. 6. 